\title{
Building Merit: The Moral Economy of the Illegal Wildlife Trade in Rural, Post-Socialist Eastern Mongolia
}

\author{
HEDWIG A. WATERS
}

Postdoctoral Fellow, International Institute of Asian Studies, Leiden University, Leiden, The Netherlands, and Honorary Research Fellow, Department of Anthropology, University College London, London, UK

Dalai is a freshwater lake located on the Chinese border in rural, eastern Mongolia, which residents have affectionately nicknamed "the oyster" for its convex depths. ${ }^{1}$ For centuries, Dalai's shores were largely unpopulated, used chiefly as a water source for roaming pastoral herds, until 1939, when the socialist Mongolian People's Republic (MPR) founded the lake's first fishing settlement, which grew into a centrally organized fish factory. In 1989, the MPR collapsed and half of the roughly eighty families stationed at the lake moved away in search of better economic prospects in the new market democracy. Now, thirty years after socialism, only a tiny fishing hamlet remains, roughly twenty patchwork houses occupied by people of non-working age (pensioners, small children) and a few dogged fishermen. Even though Dalai Village (tosgon), as it is now known to residents, remains largely unconnected to the state's infrastructure and is not found on many maps, its presence looms large in the surrounding region of Magtaal-Mongolia's easternmost county, or soum. Since the transition from socialism, the name of Dalai Village circulates in the area for its reputation as the

Acknowledgments: This paper is based on ethnography from my doctoral fieldwork but has been thrice revised and I am very grateful for the feedback I received from many actors as I reconceptualized its academic contribution. The fieldwork was carried out between 2015 and 2017 in Mongolia and funded by ERC-2013-CoG, 615785, Emerging Subjects. I wrote the initial version of this article while a visiting researcher in the Mongolian and Inner Asian Studies (MIASU) unit, Department of Anthropology, University of Cambridge. Many thanks to David Sneath and Caroline Humphrey for feedback on that version. I also presented the second version of this paper at MIASU and UCL, and thank Joseph Bristley, Joe Ellis, Sayana Namsaraeva, and Tom White, as well as Alex Pillen, respectively, for their helpful feedback. Special thanks to Martin Holbraad for encouraging me to submit to $C S S H$. Finally, I thank the anonymous reviewers at $C S S H$, whose engaged comments proved vital to the final reworking of this paper.

1 "Dalai," "Dalai Village," and "Magtaal" have been anonymized. 
fishing village that survives on the margins of legality, states, and epochs through the illegal-yet-licit sale and coordinated, cross-border smuggling of its fish.

But what makes Dalai Village exemplary is not so much its political marginality, or the speed of its economic change, but rather the social norms villagers have developed to navigate these conditions. Much social scientific work on frontier economic transformation in both post-socialist and market liberalizing contexts documents the intensification of resource extraction (of crops, minerals, or wildlife) as a common survival strategy among the poor (Botoeva 2014; High 2017; Li 2015; Sneath and Munkherdene 2018; Tsing 2005; 2015; Wiegratz 2016; Wingard et al. 2018). In Magtaal, as well, families left behind in the post-socialist transition have come to make ends meet by becoming either resource procurers-gathering for sale commonly-accessible wildlife such as fish, medicinal plants, antelope, and wolves - or resource middlemen-bulking and exporting these resources to China. ${ }^{2}$ But, while this literature often emphasizes the divergent economic stratifications that result, as people compete over scarce resources, the wildlife boom in Magtaal, as epitomized by Dalai Village, is curiously suffused with collaboration.

Indeed, although (or, maybe, because) this trade is illegal, both the fishermen and middlemen of Dalai Village share an ethos of mutual dependence. That is, they share the view that because all villagers economically rely on the success of the fish trade, each person has a duty to uphold its functioning. While living with Mandaa and Tuya, a Dalai Village family, during fieldwork in Magtaal between 2015 and 2017, I witnessed how villagers economically collaborated to enable this trade, helping each other avoid authorities, giving each other gifts and interest-free loans, sharing car rides and food, extending affordable exchange prices, and the like. But these acts were not so much the whims of charitable individuals as they were motivated by a pervasive anti-profiteering moral discourse in the village that categorized economic actions as legitimate ("good" or "virtuous," buyantai) versus illegitimate ("bad" or "selfish"). The distinction was based on whether they upheld the economic wellbeing of the whole versus the accumulation of the one. As my friend Tuya argues, our activities may be illegal, but they are moral_- "we are building merit together" (neg negendee buyan bolj bairaa baihgüi yuu). Whether forged through their memory of socialism, their post-socialist marginalization, their cultural isolation, their defense of common lands, or the hazard of market fluctuations, Dalai villagers have constructed a moral economic framework designed to sustain the group, reinforced by social pressure and threats of socioeconomic ostracism.

This article argues that the enacted moral framework evinced by the fishermen of Dalai is highly reminiscent of the Marxist British historian E. P. Thompson's idea of a "moral economy" (1971). Between the fourteenth and

${ }^{2}$ For a policy study documenting Mongolia's burgeoning wildlife trade, see Wingard et al. 2018. 
eighteenth centuries, feudal England also underwent a political-economic transformation that saw a shift away from protectionist legislation, which regulated the affordability of basic foodstuffs, towards laissez-faire market policy with food prices determined by supply and demand. In turn, with notable frequency in the eighteenth century, and when the price of grain would spike, those individuals particularly affected by these repeals would seize grain reserves - a phenomenon known as the "grain riots." In 1971, Thompson wrote his seminal article "The Moral Economy of the English Crowd in the Eighteenth Century" out of frustration with previous historical work that depicted these rioters as purely motivated by hunger. In contrast to this "crass economic reductionism" (ibid.: 78), Thompson argued:

It is of course true that riots were triggered off by soaring prices, by malpractices among dealers, or by hunger. But these grievances operated within a popular consensus as to what were legitimate and what were illegitimate practices in marketing, milling, baking, etc. This in its turn was grounded upon a consistent traditional view of social norms and obligations, of the proper economic functions of several parties within a community, which, taken together, can be said to constitute the moral economy of the poor (ibid.: 79).

Thompson's usage of the term "moral economy" to describe the social and moral motivations behind the protests of the English "crowd" became hugely prolific in the social sciences, inspiring both a worldwide search for similar crowd-based political-economic phenomena and a proliferation of studies detailing how moral frameworks influence economic reasoning.

However, this article ponders the conditions that engender a moral economy - here an anti-profiteering moral discourse that is expressed through economicleveling exchange practices socially upheld by group sanction-common to both the Dalai case study and the grain riots. Notably, grain riots often shared historical political climates that involved a shift from (or breakdown of) a paternalist provisioning system on a good (wheat, bread, or rice) considered central to societal wellbeing. Additionally, although grain riots could differ in the strength of their "legitimizing notion" (ibid.: 78), their recurrent aim was to mitigate the ability of others (e.g., traders, the elite, dealers) to profiteer off of these shifting circumstances. At Dalai, the rural, twenty-first-century Mongolian fishermen have similarly undergone a political shift from the socialist holistic provisioning system to the post-socialist market liberalization of a commodity perceived as central to their wellbeing: the economic proceeds from fish. Moreover, their anti-profiteering practices are most pronounced when dealing with traders - those in a position to take advantage of the village's shifting circumstances - and are upheld by social ostracism and refusal to work. Thus, differences in system, commodity, and sanctioning form notwithstanding, two factors 
characterize these moments: (1) the presence of a historical ethos of shared entitlement to the commons (land, food, resources), yet its increased contestation through political-economic shifts, sparking self-reflexive ire amongst the newly debarred segments of society; and (2) the crystallization of anti-profiteering discourses among the newly debarred group, which manifest themselves through economic-leveling exchange practices in the markets in the newly commodified commons' goods.

\section{PART 1: THE MORAL ECONOMY OF THE EIGHTEENTH-CENTURY GRAIN RIOTS}

Writing in 1971, Thompson used the term "moral economy" to describe a bastion of social mutuality amongst the poor that was increasingly under threat through the nascent "triumph of the new ideology of political economy" (1971: 129). He argued that governance in late medieval England was modeled on a paternalist ideal of obligation between classes, which prescribed the implementation of regulation that maintained the general interest of the Commonwealth (also "common weal" or common wellbeing). Economically, this ideal manifested itself through a mélange of statues, local laws, and customs that structured market access to and limited profiteering off of basic foodstuffs, in order to safeguard their accessibility for all (ibid.: 83-88). But, throughout the eighteenth century, the statutes of the paternal "old model" were gradually repealed as it was displaced by the emergent ideal of political economy, which maintained that the common good was best upheld by the free flow of goods via liberalized markets. The results were periodic sharp increases in the frequency of food riots. These were actions of civil protest, commonly instigated by the poor (or, variously, "the working classes," "the crowd," or "the people"), in which food reserves were stormed with the aim of redistributing them to participants at a crowd-determined price (ibid.: 112-18). More than manifestations of raw material need or hunger, Thompson asserted, the riots were triggered by, and expressed, the participants' "moral economy,": their shared notions, rooted in the paternal tradition, that it was morally wrong to profiteer off the necessities of life. The riots served as a means of rectification.

The reaction to Thompson's coinage was enthusiastic. Because his 1971 article describes an epochal shift — from the past "tradition" of moral economy to the emergent "de-moralizing" political economy (1971: 79; 1991: 201-2, 271) - his work was often read as complementary to that of Polanyi, who had argued that economic history could be divided into a pre-industrial, subsistence past and a post-industrial, amoral, formal economic future (2001[1944]). Thompson's argument initially inspired a wave of historical research that sought out similar moral economies in various cultural contexts (1991: 341-51), but it reached new audiences when, in 1976, the political scientist and anthropologist James Scott used the term to describe the "subsistence ethic" amongst the peasantry of 
southeast Asia, the historical practices of moral reciprocity developed by peasants to maintain mutual survival (1976: 2). As the social sciences gradually drifted away from Marxist to post-structuralist approaches in the 1980s and 1990s, Thompson's formulation was increasingly derided for romanticizing the past and ignoring the many moralities present within contemporary economies (Booth 1994). In lockstep with this trend, the definition of "moral economy" was gradually broadened to indicate "not only how moral ideas are expressed in our economic choices, but also ... how the organization of the economy affects social well-being" (Browne 2009: 2). The term "moral economy" remains divisive but is nonetheless undergoing an efflorescence, being used as a general signifier for diverse moral frameworks that impact economic behavior (Carrier 2018; Götz 2015; Hann 2010; Keane 2019; Palomera and Vetta 2016; Salverda 2020; Simoni 2016; Whyte and Wiegratz 2016; Wiegratz 2016).

The anti-profiteering moral ethos of Thompson's description was a product of a specific configuration of historical circumstances. Food riots reoccurred globally between the seventeenth and nineteenth centuries in contexts where a historical provisioning order governing access to a central foodstuff was being dissolved. Thompson described the rapid expansion of laissez-faire economic doctrine around 1770 (1971: 89), while Tilly discusses how food riots in late seventeenth to mid-nineteenth-century France were set against the nationalization of the grain market and shifting economic authority away from the regulatory systems of local communes (Tilly 1971; 1983). Wong argues that the rice riots in eighteenth- and nineteenth-century Qing dynastic China occurred as the state became unstable and unable to distribute the reserves in state-run granaries (1982). In each case, they were instigated mostly by the buyers of food (and their moral allies) who were most sensitive to price fluctuations (Rude 2005[1964]; Tilly 1971: 26), like small peasants in France (Tilly 1971: 26), low wage earners in England (Tilly 1983:344), and the urban and rural poor in China (Wong 1982: 771). They did not necessarily happen at times of highest poverty, and were often triggered by rapid price jumps caused by either dearth or human action (Rogers 1987; Rude 2005[1964]: 219; Tilly 1971; 1983: 339; Wong 1982). They were directed at individuals suspected of either instigating or profiting from high prices in the contested foodstuff: merchants or bakers in France and England, or wealthy feudal households in China. They took two common forms designed to limit profiteering: either a blockade to prevent export to areas with higher prices, or a storming and redistribution of reserves to prevent hoarding until prices rose (Rude 2005[1964]; Tilly 1971).

Grain riots were probably rooted in the perspective that the wellbeing of society was best served by the distributed access to necessities common to all. As an earlier corollary, Rakopoulos and Rio describe how narratives of rule in medieval England hinged on the image of the "Commonwealth," a centralized kingdom where the Crown, its (common) territory, its wealth, and the well-being 
of subjects were one (2018: 278). But, starting in the twelfth century, common lands accessible to all began to be enclosed into private plots for sheep grazing. This sparked a proliferation of riots and contestations, such as the Enclosure Riots of the fifteenth to seventeenth centuries (Liddy 2015: 41-43; Manning 1988) and the Diggers in 1649-1650 (Thomas 1969), amongst populations newly denied access to common lands (Rakopoulos and Rio 2018: 278) or motivated to defend the "common weal" (Watts 2007: 251; Liddy 2015: 5859). Similarly, Tilly makes the crucial point that although the "vague justification" (1971: $45 \mathrm{n} 48$ ) that the monarch had an obligation to see that food was available to all existed in sixteenth- and seventeenth-century France: "The moral economy, as an alternative model with a very specific content as to how government should act in reference to the commerce of grains and food prices, only appeared when governments stopped intervening in traditional ways" (ibid.: 45-46 n48, my emphasis). Here, "tradition" refers to the customary ideal of governance as regulating "the commons" - the political whole and their ties to the land (Watts 2007: 245) —in the name of greater shared wellbeing.

Based on these patterns, the eighteenth-century moral economy of Thompson's description was likely not a narrative coherently formulated in the past, but rather a medieval societal norm of shared access to life necessities (land and food) that were distilled as political-economic changes threatened it. Those that found their livelihoods made newly vulnerable became cognizant of this shift, self-reflexively giving voice to these historical norms and crystallizing their manifestation as prices upheld through the sanction of grain riots.

PART 2: THE FISHERMEN OF DALAI AND THE DISSOLUTION OF PATERNAL AUTHORITY

Like the idealization of the Commonwealth, pre-socialist Mongolia was also suffused by hierarchically-inclusivist governance ideals that ensured shared access to common lands. During socialism, these holistic narratives were reformulated to legitimate the centrally organized state, which utilized diverse resources from common lands to uphold the wellbeing of all workers. However, with the advent of the post-socialist, democratic Mongolian state, these holistic narratives were increasingly challenged by market liberalization policies. Roughly thirty years after socialism, the majority of Magtaal's roughly three thousand citizens, including the population of Dalai Village, now earn their livelihood from procuring freely available wildlife resources from the commons (such as medicinal plants, fish, wolves, hay, and antelope) and either selling them at market prices to Mongolia-based middlemen or smuggling them in cars across the border to sell in China. Although these practices are often illegal, the local populations consider them not only necessary for survival, but morally legitimate according to an emergent narrative revolving around the concept of the "homeland" or nutag. Accordingly, the children of the nutag-those born and 
raised in or ancestrally traced to a specific soum - are entitled to take resources from its commons to survive and, thereby, uphold the long-term wellbeing of the nutag. In this way, the ideal that all can take from the commons for societal wellbeing has been reformulated to justify resource extractions - here resources converted into monetary provisioning - by rural poor people who have been debarred through post-socialist legislation from partaking in their entitlement.

\section{Historical Narratives of Hierarchical Socio-Economic Inclusion}

Because the historical pastoral occupants of the Mongolian steppe required rotating land access for grazing, their sociocultural systems have developed to maintain the shared and "custodial" usage of land as a common good, to sustain temporary access to it without undermining public utility (Sneath 2002: 196-97). In various forms across history, Mongolian pastoralists have been grouped into roaming civil-military administrative units under the supervision of aristocratic lords, who nominally "own" or control lands, but supervise shared access to maintain viability of the unit's herds (Sneath 2002; 2007; Atwood 2012). When, in the sixteenth century, Tibetan Buddhism was re-introduced to the steppe, it took a form that complemented this political-economic system (Bawden 1958; Humphrey 1995). It conceptualized the land as populated by powerful spiritsthe land masters (gazryn ezed) - that lived in large land formations like lakes or mountains and imparted fertility on the land and crops. In the seventeenth century, Outer Mongolia, the area of contemporary Mongolia that includes Magtaal, became a suzerain territory under the control of the Qing dynasty, and these worldviews were combined into the emergent feudal administrative unit known as a hoshuu (Sneath 2002: 198; Atwood 2012). Within a hoshuu, everyday herders were ranked into different classes under the supervision of a hereditary lord (or monastery), but all people shared rotating access to, and had the spiritual and political duty to uphold, the viability of grazing lands, nominally "owned" by the Qing emperor and local deities (Sneath 2018: 334-36). Thus, although imperfect in practice, ${ }^{3}$ at the turn of the twentieth century the dominant governance model was a hierarchically-inclusivist ideal that posited all members

\footnotetext{
${ }^{3}$ Sneath describes how, in practice, the best lands were still reserved for the nobility who, in the nineteenth century, occasioned to sell land for profit, which was met by official censure from the Qing government (2018: 335). In fact, in the latter half of the nineteenth century, economic burdens on the lower classes in Outer Mongolia increased, either because of increased demands from lords, increased dependence on Chinese merchants, or both. This resulted in an increase of grievance petitions to the Qing court instigated by the lower classes (Ochir et al. 2003: 249-73). Occasionally, unresolved grievances sparked vigilantism among the lower classes in the form of armed revolts, or the formation of roaming bands - known as "good men of the wilderness" (shiliin sain ers) - which were rumored to steal from the rich (i.e., Chinese merchants) and give to the poor (Natsagdorj 1963). In official petitions, the peoples in revolt would often appeal to the paternal governance model in their formal explanations of motive vis-à-vis the court, arguing that they were trying to rectify and uphold it (Veit and Rasidendog 1975).
} 
of a unit as entitled to temporary usage of public lands to maintain group wellbeing (Sneath 2002: 201).

The arrival of socialism with the founding of the Mongolian People's Republic (MPR) in 1924 did not so much contest this model as integrate it into the centrally organized state. With the transition, private ownership was dissolved and herds were collectivized, as land became newly conceptualized as state property granted for free and perpetual use to herding cooperatives (Fernandez-Gimenez 2010: 327-32). In 1939, Magtaal became the MPR's easternmost soum, or county province, containing a nedgel - a herding cooperative under the supervision of the soum leader that grazed in its territory - and the first fishing workshop at Dalai Lake. In 1954, this fishing spot was expanded into a centrally organized fish factory, as eighty families were relocated to the lake as its workers. In 1972, an agricultural cooperative was founded to the southeast of Dalai Lake, which became a collective micro-city and entailed the resettlement of hundreds of families there. ${ }^{4}$ The ideal of governance during this period was one of paternal inclusion and collective striving, as indicated by a socialist sign that still hangs in Magtaal: "The state is the master of the person, the person is the jewel of the state" (Hümüünd tör erhem törd hümüün erdene). The workers of Magtaal did not subsist directly off the bounty of their labor-Mongolians were not keen to eat fish - but they worked cooperatively to produce from the collective land in the name of the state, which was then expected to provide provisioning and care in return. Both the fish factory, which exported fish as far away as Bulgaria, and the agricultural cooperative, which won several productivity awards, boomed until the gradual collapse of the MPR in 1989-1991.

\section{The Rise of (Illegal) Resource Entrepreneurialism}

It was not the shift from feudalism to socialism, but rather from socialism to market liberalization that challenged these holistic sociopolitical legacies. In the first years of the fledgling Mongolian state (1991-1994), the government carried out a series of broad market liberalization reforms aimed at constructing and furthering private property regimes, national markets, and citizen entrepreneurialism. In 1991, for instance, both the fish factory and agricultural cooperative were dissolved by a privatization reform, which distributed their assets such as machinery and animals through vouchers to their former workers as private property. But land was not privatized in the same manner. When the Mongolian Constitution was adopted in 1992, it collectively framed the land and its assets as subject to the people's authority and under the protection of the state (article 6 , clauses 1 and 2), which may distribute or govern it according to reasons of public health, the environment, or national security (article 6, clause 4). In 1994,

${ }^{4}$ The soum's population peaked at 4,308 in 1989, according to the Aimag Statistic's Office. 
the new government, encouraged by international donor agencies, debated the privatization of land, but many of the more "conservative" members of parliament were reluctant to do so out of fear of limiting pastoral herding (Sneath 2004: 165). In compromise, in 1994, the parliament passed the country's first Land Law, which created a category of land leasing, known as ezemshil or temporary possession, where a plot was technically still the property of the state but could be leased to herders or companies with long-term and exclusive access for up to sixty years (Plueckhahn 2020: 102-5).

In addition to the privatization of assets, the fledgling Mongolian government also scaled back welfare and state expenditures while solidifying borderopening agreements. In Magtaal, this combination sparked a conflagration of entrepreneurial commodification of the environment, as the populace found itself largely unemployed yet surrounded by capitalizable assets. Initially, between 1991 and 1994, the population, including Dalai, shrank as individuals of working age fled these remote settlements to seek new opportunities in urban centers. But, as residents tell, a Mongolian businessman arrived at Dalai in the early 1990s and offered to buy the vouchers off the former workers with the intention of reopening the factory as a private business. This company operated at the lake for ten years, seasonally employing Chinese fishermen, who arrived in the soum and were shocked to find freely available Fang Feng, ${ }^{5}$ a Chinese medicinal root valuable in China in its wild-grown and thereby "organic" form. On the side, these workers hired a local Mongolian to become a changer-a middleman who told the populace how to gather the root and offered to buy it from them for sale to China. In the early 2000s, the private fish factory dissolved due to a drop in the fish prices in China and a similar changer network developed at Dalai. Throughout the early 2000s, any unemployed individual in Magtaal either went to Dalai to fish ${ }^{6}$ or combed the steppe for the Fang Feng plant, or often both. Paradoxically, the land thus became a public commons yielding resources that individuals privatized into cash assets for their post-socialist economic survival (Sneath and Munkherdene 2018).

Gradually, this trade became legally circumscribed. In 1995, the Mongolian government passed its first wildlife legislation, the Law on Hunting, Resource Use Payments \& Fees, which cast game wildlife (an am 'tan) as the property of the state that citizens could utilize through a system of fees and royalties. This law was complemented in 2000 with the passing of the first Law on Hunting

\footnotetext{
5 The plant is also known by its Latin name Saposhnikovia divaricata. The extraction of Fang Feng is currently (2021) booming across Inner Mongolia, Central Asia, and eastern Siberia (S. Namsaraeva, personal communication, 2021), in order to satisfy the ongoing demand for noncultivated, wild-growing medicinal roots in mainland China.

6 Three main types of fish in Dalai Lake are popular for sale in China: Asian carp (Ru: sazan; Mo: buluu tsagaan), catfish (Ru: soom) and common carp (Ru: kras; Mo: algana), with Asian carp being the most lucrative. The prices in this article are based on the Asian carp market, which dominates everyday discussions of market conditions in Dalai Village.
} 
(later superseded by the 2012 Law on Fauna), which regulated conservation and trapping relations around large game, birds and fish; and established a permit system for industrial, domestic, and special purposes, as well as fines for violators. ${ }^{7}$ This law also stipulates a total ban on fishing at Dalai Lake for domestic and special purposes between 15 May and 1 August of each year (article 13, clause 2.4); likely because this is the fish spawning period. At Dalai, this "appearance of paper" (Guyer 2004: 156), such as state-recognized contracts, permits, and identity cards, that accompanied the process of formalization and legalization effectively marginalized local actors from more lucrative forms of fishing, because they lacked the contacts, money reserves, or legal knowledge to apply for permits. Starting in the mid-2000s, other Ulaanbaatar-based private companies began applying for seasonal permits to export fish from Dalai in the winter, when the price was especially high in China due to Lunar New Year. Every November, these companies would move to Dalai and employ the local fishermen as seasonal contractors, extending their state permits to them. But rather than fish exclusively for the company, the Dalai fishermen used the company permit as a smokescreen to also sell a portion of their catch to changers at higher prices. This loophole ended in 2015 when the Chinese government made the formal export process more hygienically demanding, which dissuaded urban companies from going to Dalai.

\section{"Doing it for life"}

Magtaal residents are aware of recent shifts in the political-economic system, yet they still frame their ideal governance relation in terms of holism. For example, the contemporary Mongolian term for economy, ediin zasag, can be directly translated as "the governance of property" and encapsulates the understanding that that realm of material relations ( $e d$ or property, thing) should be administered (zasah, or to govern) by the sovereign head for the wellbeing of all (Sneath 2002: 201-2). Ideally, this relation of hierarchical yet inclusive governance would repeat itself on multiple societal levels, as indicated by an associated idiom: "First govern yourself, then govern your home, and then govern the state [biyee zasaad geree zas, geree zasaad töröö zas]" (Plueckhahn and Bumochir 2018: 346-47). But while carrying out fieldwork in Magtaal between 2015 and 2017, I often encountered these frameworks in the negative: as the example of what the government and politicians should do but were not doing. In 2016, I visited Zurhee, a fishermen born in Dalai in 1964, right after a local politician had swept through the village asking for votes for an upcoming election. When I entered, Zurhee threw the politician's pamphlets to the side and exclaimed: "They all say

\footnotetext{
7 According to the Law on Hunting, permits for special purposes can be obtained from the central government (article 11), whereas industrial contracts can be entered into with the soum government, which requires the payment of fees and the hiring of professional trappers (articles 8 and 9).
} 
nice things before the election - that they will legalize fishing - but then do nothing." I asked him what kind of person he would support, and he explained: "They would have to support the people. Someone who looks out [harah] for the people would be a good person... They should first govern their body, then make their home nice, and then they can govern the state." Zurhee's statements are reflective of the continued sentiment in Dalai that an ideal sovereign (now a politician and government) would show care for everyday people, that is, look out for (harah) or be considerate of (bodoh) them, but that such historical ideals are increasingly at odds with the reality of the contemporary system.

Indeed, at Dalai, the combination of market liberalization and the gradual illegalization of the only form of employment available to residents, fishing, placed residents in a moral double bind. Since the early 2010s, companies with legal permission to fish stopped arriving at Dalai, and any new industry in other fields in the soum, such as agriculture or oil, preferentially hired urban Mongolians and bypassed the local populations. As of 2015, for example, two-thirds of Magtaal remained formally unemployed. ${ }^{8}$ At the same time, as Zurhee explained, illegal or permit-less individuals kept popping up at the lake offering to buy fish, such as Chinese buyers, permit-less Mongolian companies, and changers. Here, existential material conditions clashed with long-held beliefs leading to, in Zigon's terms, a "moral breakdown" (2007: 133), as residents became cognizant of their inability to continue their livelihoods in the customary mode. Throughout my fieldwork, the rallying cry of "life"- the need to defend life, uphold life, do it for life, or meet the demands of life ${ }^{9}$ - was repeated as the "ethical demand" that sparked a reconceptualization of local dispositions vis-àvis the law and political traditions. Zurhee, for one, argued that the law was not "fit for his life," since if he followed it his life would become "very difficult," and thus he decided that the fishermen needed to "forget traditions in order to live their lives" (Am'darlyn tölöö yos züig martana). Consequently, as has been found in other studies on the ramifications of market liberalization amongst the rural poor (High 2017; Roitman 2005; Wiegratz 2016), residents adapted their historical moral expectations to legitimate what were previously maligned illegalities, which now sustained their lives.

Because the entire township, collectively, has undergone this shift and is, in some manner, dependent on illegal resource entrepreneurialism to survive, the participants in these activities enjoy high levels of coordination and sympathy in the soum. In 2017, I interviewed an official in local government who had been elected after working as a nature protector for eight years and who admitted that the fishermen's activities were public knowledge. But for nature protectors, he

\footnotetext{
8 This is according to statistics from the local Magtaal government.

9 Examples of relevant statements are: [we need to] "supply livelihoods"(am'dralaa zalguulah), "we do it for life" (am'dralyn tuld), "we are thinking about life" (am'drahyg l bodno), and "life demands it" (am'dral shaardaj baina).
} 
explained, cracking down on this trade was a "personal dilemma" (hünii huv'd hezü̈̈ asuudal). For one thing, he said, echoing Zurhee's language, the participants were doing it to sustain their families within a system that did not provide them with work or aid - the law "did not fit the reality of life" (bodit am 'drald taardaggüi). At Dalai, in particular, the trade had become very "refined" (nariin), as individuals living in the township center would call their relatives at Dalai as soon as they saw a ranger car heading in the lake's direction, sparking a warning telephone chain. Moreover, many of the nature protectors were directly or indirectly involved in resource trades themselves, either because they were related to a participant or even, in some cases, because they themselves participated on the weekends for extra income. In general, he admitted, public officials were not that interested in penalizing everyday resource entrepreneurs, "because it would cause all sorts of problems in the soum." By one informant's estimate in 2017, up to 80 percent of the soum (including underpaid rangers) was involved in the wildlife trade, leading to high levels of organization among fishermen to avoid raids and demotivation among rangers to try and catch them.

\section{Entitlement to My Homeland}

In lieu of these historic holistic ideals fracturing into competing individuals, in Magtaal political-economic models shifted into a new binary construction. The holistic models of the past framed political sovereigns, their populace, and the land (as spiritual and political-economic source) as intertwined; now, the people and the land are increasingly conceptualized in opposition to their sovereign head(s). Throughout my fieldwork, Magtaal citizens repeatedly distanced themselves from their political leaders in the central government in Ulaanbaatar, believing their interests to contradict, be out of touch with, and even harm the needs of local peoples. They increasingly associated with a concurrently spiritual, locally-nationalist, class-based, anti-elite narrative of collective identity. In interviews concerning political/state issues and when generally discussing the political-economic needs of locals, the citizens of Magtaal self-refer using two narratives: as members of a lower-class, politically ignored collective- "the people" or "the poor" — or as members of a "homeland" (nutag).

On the one hand, Magtaal residents used a plethora of hierarchically spatialized, class- and wealth-based terms to describe this perceived waxing cultural and political chasm. Locals were variously described as "the people" (ard tümen), "the poor" (yaduuchuud), and "the working class" (har borchuud); while politicians were labeled with terms like "elites" (elit), "the big bosses" (tom tom darga nar), "the lords" (ezenten), and "the high rankers" (deedchüül). The term ard tümen for "the people," easily the most common self-designation in Magtaal in anti-elite discourse, is a neologistic compound created during socialism from the feudal term for "commoner," ard, and "myriad," tümen (Sneath 2010: 252-53). The term har borchuud literally means "the black and brown 
people," but can be figuratively translated as "the working class," because both "black" and "brown" were designations for different underclasses during the presocialist feudal era and were reconceptualized into designations for the proletariat during socialism (Bawden 2015; Sneath 2007: 51). In Magtaal, residents defined this term as representative of the color of one's skin after doing hard work in the sun, illustrating it with the phrase "black and brown work" (har bor ajil).

Yet, as historical pastoralists, Mongolians are affectively attached to the birthplace of their ancestors - their "homeland" (nutag) — under the understanding that the "land masters" of that earth nurtured their lineage over time. The development of nationalism in socialist and post-socialist Mongolia elevated this concept to a "sacred principle" (Sneath 2010: 256), often as a stand-in for the Mongolian nation-state as a whole. But in the post-socialist period it has also been frequently used to make political/economic alliances and claims in and over rural areas, for example the claim that individuals must collectively share and work together because they share a rural "homeland." In Magtaal and Dalai, residents often collectively refer to themselves - as, for instance, "my village people" (tosgoniihon), "my people" (manaihan), or "my homeland people" (manai nutagiihan) - and use the term nutag in describing relations with the land masters or in contradistinction with individuals from other homelands.

In contemporary Magtaal, these two collective concepts overlap into a narrative of political-economic entitlement based on shared homeland. ${ }^{10}$ Even on the macro or urban level, the narrative of "resource nationalism" has been on the rise in recent history. This is a nativist or protectionist economic discourse that Mongolians have greater claims to the proceeds of the nation's mineral resources than do foreigners (Myadar and Jackson 2019). On the micro, rural level, Sneath and Munkherdene have noted a rise in claims that residents from a rural area also have greater entitlement to the resource reserves on account of their homeland belonging - a discourse called "nutag-ism" (2018: 822-83). Zurhee expresses a similar narrative: "Outsiders don't live in this place, so they don't love our lake. The local residents think it is our lake and we love the lake. Outsiders just think it's like any other place; it's just someone's 'homeland,' doesn't matter to me. 'Loving' means to take trash from the lake and don't leave your net in the lake [and] clean it."

10 According to Liddy (2015), a strikingly similar narrative shift of political entitlement existed within urban England in the fifteenth to sixteen centuries in the context of enclosure riots. In late medieval England, burgesses in towns and citizens in cities had a notion of citizenship that was similarly hierarchical yet inclusive. After swearing an oath of enfranchisement to towns, citizenship was envisioned as membership in an urban cooperative that linked people to the local land and its political jurisdiction (ibid., 54). Within this discourse, the "common weal" was directly connected to the township's common lands (ibid., 59), which were envisioned as part of the corporate liberties citizens swore to uphold at enfranchisement into the township body. Commoners judged their city councils by their upholding of these joint rights, which, when violated, provoked enclosure riots from the citizenry. 
At both Dalai and in the soum as a whole, residents not only argue that they need resources for life but opine that the local resources are "theirs," either because their families have lived there for generations or because they have a spiritual relation to the homeland master. This shared perception that individuals have a claim to resources to sustain their lives yet are being actively thwarted in this claim by the contemporary political/economic/legal system creates the sense that "they" need to jointly organize to maintain their right, particularly vis-à-vis "outsiders" (gadny hümüüs) and the political elites. The overlap of these discourses, with residents feeling they are simultaneously the politically ignored poor, the people, and the homeland-entitled, has likely crystalized a particularly unified sense of group political/economic mutuality and self-defense.

\section{PART 3: THE MORAL ECONOMY OF MERIT}

The realm of the commons is more than the technical management of commonpool resources; it is the production of interdependent subjects over time (Velicu and Garcia-Lopez 2018). The term "commons" is most often associated with the economist Ostrom, who defined it as a common-pool resource, such as land, water, or air (1990). But critics of Ostrom have expanded the materialist perspective to describe the practices of "commoning," meaning the acts of sharing and the worldviews of interdependence often present within communities that share a common resource (Linebaugh 2009). In historical Mongolia, actors' hierarchical-yet-inclusivist usage of common land was not only governed by the political-economic system but undergirded by a Buddhist-inflected cosmology of spiritual interdependence with other living beings. In the post-socialist economy, though, local individuals are no longer directly dependent on common-pool land and herds for subsistence, but rather on monies from exchanges of common-pool land resources. Historical cosmological narratives have been shifted to adapt to these new circumstances. Now, resource-based economic exchanges - that is, exchanges socially earmarked by the products of the commons - are governed by a moral economy that incentivizes mutually-beneficial exchanges. These are legitimated as "virtuous" or buyantai, and opposed to uneven accumulation, which is denigrated as "selfish." This allows local people to collectively thrive and maintain their commons-based livelihoods within the contemporary economy.

\section{Historical Cosmologies of Commoning}

In nineteenth-century Mongolia, although the human sovereign governed and oversaw the usage of land, its "true" owners were the land masters that populated it. Accordingly, pastoral herders perceived weather conditions and the fertility of the land - the growth of grasses, animals, berries, et cetera - to be an effect of the land masters' fortune or hishig — a spiritual, life-giving energy that circulates 
through all living things (Empson 2011). ${ }^{11}$ Because land masters were wily, powerful creatures, herders often participated in annual appeasement rituals with the aim of calming and cajoling them to impart favor on their families in the form of good weather, bountiful resources, or new human births. In turn, herders were allowed to take from the land to continue the cycle of life by maintaining their families, but never in a manner that undermined the hishig cycle as a whole (Humphrey, Mongush, and Telengid 1993). For this reason, herders often observed injunctions on acts that damaged the land in some capacity (e.g., breaking twigs or digging in the ground) (High and Schlesinger 2010). Moreover, an individual's or family's fortune could be strengthened by performing good acts expressed through the Buddhist term "merit" or buyan, like reading scriptures, good management of the self and family, charity, ritual participation, and giving alms (Empson 2011: 73). ${ }^{12}$ Performing such acts could encourage masters to impart more fortune in this lifetime or strengthen one's karma to encourage a better lifetime in the next. Thus, combined, these narratives construct a worldview of living beings mutually dependent on a cycle of energy that requires tempered maintenance and good acts to maintain and, in doing so, brings good fortune to all participants.

\section{Building Merit Together}

Of course, in contemporary Magtaal most residents no longer subsist directly off the land, but by converting its resources into money. Returning to Dalai Village, by 2015 , all permitted fishing had ceased and the residents had become adept at fishing and selling their catch "illegally" (hulgaigaar) to whomever arrived at the lake. In 2016, Mandaa, a forty-two-year-old fisherman born and raised in Dalai Village, copied the Fang Feng trade by building a hidden compartment into his car, stashing fish there, and smuggling them across the border. Bringing them to market a few times in the nearest Inner Mongolian, Chinese city, he eventually struck up a friendship with an Inner Mongolian man who could sell his fish. For the first year, Mandaa and his wife, Tuya, took turns going back and forth, alternately fishing and exporting, until they realized they could save time by

\footnotetext{
11 The term hishig or kesig has undergone many semantic shifts with different political systems but is repeatedly concerned with different forms of "worshipping grace" from a (mortal or immortal) hierarchical power. Atwood argues that, whilst kesig was appropriated by the Qing Manchu rulers of Mongolia (1635-1911) to signify favor imparted by rulers to their subjects (with expectations of gratefulness and self-abnegation), it has diverse older meanings concerning the reception of ritual or sacrificial food (from ancestors or Heaven), participation in which confirms membership in the community (2000: 114). Today, in addition to indicating interactions with land masters, the term is occasionally used to describe hierarchical state action carried out in the name of the greater communal nation, for example when the state distributes mining rents to everyday citizens.

${ }^{12}$ Moreover, the terms are often combined as a pair-buyan hishig - to emphasize the larger cosmological cyclicality of the process (Empson 2011: 73). For example, doing good acts as buyan can increase one's hishig, which provides more opportunities to do buyan, et cetera.
} 
focusing exclusively on exporting. In 2017, they started going around to all the fishing houses in the village and buying fish from others at the going Dalai Village rate, which they would then export in mass. Everyone would benefit, they emphasized, because Mandaa's family (like other smugglers or changers with cars) was able to set up another market avenue for themselves and the rest of the village, whose economic opportunities were otherwise restricted by legalities. Since 2016 (and ongoing in 2021), the villagers of Dalai have earned the bulk of their subsistence through participating in these coordinated resource exports.

Mandaa was a popular figure in the soum. Months after doing fieldwork at the lake, my research partner and I were sitting in a yurt cafe on the other side of Magtaal and overheard a conversation between strangers about how great he was. In contrast to the widespread reputation of middlemen as individuals who prioritize their economic profit and take advantage of power differentials to exploit procurers, Mandaa was a resident, born and raised at the lake, who tried to buy fish from residents at prices that suited them. Previous changers and companies that had come during the winter season had often taken advantage of locals' lack of cash and legal negotiating ability to indebt fishermen or receive fish at a depressed price. ${ }^{13}$ In contrast, Mandaa and Tuya incorporated the price fluctuations and the going-rate in their negotiations with fishermen; would sell them nets or give them loans without interest and accept payment at the going rate; and often gave fishermen they constantly worked with gifts, or free rides to China for various needs. When I asked Tuya about their activities, she emphasized that the locals all knew each other and were all trying to feed their families, so "those individuals that can cross the border, should buy from the others-we are doing a good deed [buyanii ajil]." The narrative of moral virtue often accompanies these retellings_- "we are building merit together" (neg negendee buyan bolj bairaa baihgüi yuu), she opines when describing the villagers' economic collaboration.

Tuya and Mandaa's usage of the term "buyan" can be generally translated as "doing good," which is a common contemporary lay-Buddhist understanding of the term (Abrahms-Kavunenko 2019: 130). For example, in this quote by Tsegii, a revered Magtaal teacher and store owner, she argues that the flows of both buyan and money are governed by the moral adage that you give what you get:

If you give more to the government, you can take more, if you give less, you take less. If you give your buyan to others, you get buyan from others. It's a rule of money-the more you give, the more it grows well and comes back.... If children

\footnotetext{
13 For example, one Dalai fisherwoman described how she had needed a new fishing net, so a changer offered to sell her one in return for fish. Only, each kilogram of fish he would accept as payment for the net would be counted at the reduced price of 3,500 MNT in a season with a market price of $6,000 \mathrm{MNT}$.
} 
[come into my store] and don't have enough [money] to buy things, like 10 or $15 \mathrm{MNT}$ are missing, then I'll just give it to them. Next time, it will be my income.... Mongolians like to sponsor rites or give to others, because it will come back like buyan.... It's a question of intention; greedy people are difficult [to deal with]. If you are greedy, people don't like you.

On one hand, Tsegii's multiple usages of buyan draw attention to an important parallelism: that the mundane, this worldly, and the profane, other-worldly, dialectically ricochet. Within recent Mongolian ethnographic literature, money has often been depicted as an amplificatory conduit of the spiritual intent of its user. For example, money engendered from spiritually-negative acts, like gold-mining, is sullied (buzartai) and must be controlled to limit negative reverberations (High 2013), whereas urban participants in Buddhist moneycalling rituals sacralize specific notes to "pull" additional positive wealth (Abrahms-Kavunenko 2018). But, in both Tsegii's and Tuya's usage, buyan has taken on a secular distinction as participating in and upholding relations of economic reciprocity that will engender collective wellbeing. ${ }^{14}$ As opposed to economic acts that are "selfish" and only benefit the wellbeing of one, both the ideal state and Dalai Village are depicted as fields constituted by many acts of economic aid that uphold the whole over time.

\section{Merit-Making Prices}

In addition to the narrative that changers like Mandaa are doing "good deeds" (buyanii ajil) when they provide employment to unemployed fishermen, local changers often strive to buy from fishermen at the "meritorious opportune price" (buyantai bolomjiin üne; shortened as "merit-making price"), being a price seen as beneficial to both actors. This conjunction of a virtue with economic price setting is highly reminiscent of Thompson's discussion of the just prices ${ }^{15}$ demanded by the grain rioters. Specifically, rioters outraged by attempts by different tradesmen to profit off of high grain prices would storm their stores and, fascinatingly, instead of absconding with grain, often resold it to the

\footnotetext{
14 Swancutt also describes the presence of the moral categorizations of "virtuous" (buyantai) versus "unvirtuous" (buyan bish) behavior among Buryat Mongol shamans in eastern Mongolia, but she focuses on how "good" versus "bad" behavior invites different spiritual entities to variously interact with humans (2008). Importantly, although Swancutt's fieldwork was not far from Magtaal, her informants are highly influenced by shamanism, whereas Magtaal is a predominantly Khalkh Buddhist area. These regional differences have influenced divergent local definitions of buyan.

15 Although often associated with debates concerning the "just price" (Luetchford and Orlando 2019; Walsh and Lynch 2008), Thompson notably did not use this exact term himself, instead referring to the "popular price" (1966: 66) as a price determined to be legitimate and reasonable by the crowd. Philosophical discussions concerning a just price are often traced back to medieval thinkers such as Thomas Aquinas, who accepted commerce as legitimate so long as it furthered and was constrained by moral considerations (Walsh and Lynch 2008: 120).
} 
participants according to a commonly accepted price (sometimes leaving the money for the tradesman) (1971: 108). As a result, Thompson argued, the rioters were not motivated only by hunger, but also by a moral notion of what was considered right or "just" in payment for a "prime necessity of life" (ibid.: 9293). Generally, contemporary analyses of the just price describe it as a manifestation of the commensuration dilemma: it emerges in contexts where actors deem there is a mismatch between the social valuation of an object and its economic price (Luetchford and Orlando 2019: 4). At Dalai, the merit-making price is relational (Roitman 2003) in that it considers the standing and interdependence of the two actors within larger concepts of societal wellbeing. And it is chiefly guided by the consideration of whether both actors are mutually benefiting from the exchange, or one actor is unfairly benefiting at the expense of the other.

Specifically, the usage of the adjective "opportune" (bolomj, also "possible") in the full conjunction draws attention to proportions in exchange. Bilguun, who has been both a fisherman and Fang Feng root gatherer, explained how middlemen differentiate themselves through the prices they offer to procurers:

A middleman's job is just work. Middlemen can make people's lives better. They can gather the resource of the people [ard tümen] and export them, which garners large merit, merit in this lifetime. If you are a real middleman, it is merit. For example, if you buy the roots from people and say, "These are bad and dirty," you are a bad middleman. But a real middleman does not see a huge amount of profit. They aren't greedy. If they are greedy, they will be cursed by local people.

Here, Bilguun's wife jumps into the conversation to clarify the meaning of "merit": "Merit means 'to help [buyan gedeg n' tuslamj]." Then Bilguun resumes his explanation:

A real middleman collects [Fang Feng] roots at the meritorious opportune price [buyantai bolomjiin üne]. For example, a price could be 10,000 MNT [around US\$4.00], but one middleman complains and says he will only pay 6 or 7,000. But if another comes and says he can pay 9,000, then that is merit. You will attract people and get more loyal partners [ünench tünsh]. The bad changers only think about themselves [öörsdiigöö boddog].

In Magtaal, almost all people are dependent on the money engendered in exchange for local resources at market prices that they have limited control over, but they can affect their profit margins in singular exchanges. For example, in the winter of 2017, the going rate for fish in Dalai was 6,000 MNT per kilogram, but it could be sold for 18,000 (or more) in the neighboring Chinese city, which makes a profit of 6,000 for the fishermen and (at least) 12,000 for Mandaa. The "opportune" aspect refers to price possibilities: the going rate is 6,000 , but 
Mandaa theoretically could offer more without taking a large personal hit. The "merit-making price" is thus a price that is offered by the middleman that cuts into their profit margin in the favor of the fisherman. ${ }^{16}$ Buyan is used by Bilguun and his wife to describe situations where the more powerful actor engages in acts of economic reciprocity - creates employment, is relatable and pleasant, gives favorable prices, and so forth — instead of maximizing their profit ("thinking of themselves" or being "greedy"). In the short term, these acts allow both actors in the exchange to benefit, which, over the longer term, upholds the common wellbeing of the soum.

Finally, Bilguun's comments point to another aspect of this discourse: its social sanctioning power. Within a context where all local people are involved in some capacity in resource exchanges, Mandaa and other changers, especially if they are from Magtaal, do not want to contradict the prevailing sentiment lest it provoke outrage and have disastrous effects on their business and ability to live in the soum. For one thing, because of the market outlet in China, local resources are in high demand and procurers can afford to be picky regarding changers. It is thus in the interest of changers to provide attractive prices because it garners the accolade of merit and, with it, a reputation in the community that attracts more "reliable partners." During my fieldwork, changers (and Chinese fishermen) that came from other areas to do business in Magtaal often offered low prices and were therefore ousted through social pressure from the community. Either locals would refuse to work with them, or they would use rumor (in Bilguun's words, "curses") to tarnish their reputations. In the same manner that residents would use phone chains to avoid patrols, they would use anonymous phone tips to tell the authorities the location of changers that were locally disliked. Through a confluence of factors - including but not limited to the shared feeling of entitlement to common resources; the isolation of Magtaal from other areas; the proximity to China; the illegalization of their livelihood practices; and the mutual dependence of all soum members on the same trade - the pressure to conform is so strong because most residents feel that their political entitlements and individual interests are best upheld by defending the wellbeing of all against the accumulations of individuals.

\section{CONCLUSION}

A specific convergence of factors engendered an anti-profiteering moral discourse common to Dalai Village and the eighteenth-century English grain riots. First, in both, society had historically been ideally governed according to a ranked yet holistic model that distributed access to the commons-the "necessit[ies] of life" (Thompson 1971: 92) - in the interest of total societal

\footnotetext{
16 The changer still often makes a larger cut of profit. Procurers generally do not begrudge the changer their margin, since they are "facilitating the process" (yavuulakhyn tuld), if they give back in terms of benefits and working conditions (for similar calculation, see Long 2001: 125).
} 
wellbeing. However, the distribution of common goods had been recently liberalized and consigned to economic markets. Certain segments of society, particularly those individuals now dependent on these exchange prices for survival, became cognizant of and morally outraged by their recent loss, and created a moral economy in an attempt to either rectify it or uphold the holistic wellbeing of the debarred group in the new exchange-based economy. Although the general political-economic trajectory is the same, there is a crucial difference between the regulated commodities in the two cases. Whereas the livelihood of the English poor was dependent on the purchase price of bread, the livelihood of the rural poor of Magtaal is dependent on the sale price of natural resources. Here, there is no direct equivalent to riot in Magtaal because, whereas the English poor could rectify purchase prices by actively seizing grain from dealers and setting the price, the rural poor of Dalai can only collectively affect sale price by compelling each other (to not accept or offer low prices), using social pressure as a monopolization tactic to maintain crowd-accepted prices and to scare off nonadhering individuals (changers, Chinese traders, "selfish" others) with the threat of group sanction and the law.

Therefore, the moral economy of merit does not represent a throwback to the past, but it does indicate a re-delineation of the holistic social body, indicating exactly who and what is included and allowed in the political commune of the commons. In pre-socialist Magtaal, herders were encouraged to moderately use land and its resources for subsistence, sharing access with others according to hierarchical cosmologies of human/non-human interrelationality. In socialist Magtaal, the land was ideologically conceptualized as a material realm collectively worked by everyday people, who gave their yields to the state and received provisioning in return. But the moral economy of merit of post-socialist Magtaal, contrary to pre-socialist cosmologies, does not condemn the extraction of nonhuman life to the benefit of the human. Contrary to the ideologies of socialism, it accepts the conversion of resources of provisioning into cash that accumulates, and does not expect dealers to take zero capital profit or negative returns in the name of the greater good (Walsh and Lynch 2008: 132). Rather, faced with the existential threat of being completely severed from the commons by markets and political leaders, local fishermen reconceptualized historical narratives into specific market exchange practices that differ from the market liberal ideals of the post-socialist Mongolian state mainly in their emphasis on group, not individual, accumulation. It is probable that the moral economy emerged in conceptual tandem with Homo economicus. ${ }^{17}$ Here, the enclosing of the land and its

\footnotetext{
17 Hann suggests that the moral economy concept remains popular within academic writings as an antidote to the Homo economicus ideal of neoclassical economics; the assumption that individuals are chiefly and ideally motivated by self-interested gain in exchange (2010: 192). Within this study, Homo economicus and moral economy are co-constitutive polarities within a material exchangecentered worldview: the first, emphasizes one-sided competitive maximization in exchange, the other distributed proceed benefits within exchange.
} 
resources has sparked the gradual hemming in of definitions of the commons and the collective social body entitled to it - now, the cash proceeds of marketable wildlife and the human occupants of the nutag, respectively.

\section{REFERENCES}

Abrahms-Kavunenko, S. 2018. Mustering Fortune: Attraction and Multiplication in the Echoes of the Boom. Ethnos 84, 5: 891-909.

Abrahms-Kavunenko, S. 2019. Enlightenment and the Gasping City: Mongolian Buddhism at a Time of Environmental Disarray. Ithaca: Cornell University Press.

Atwood, C. P. 2000. 'Worshipping Grace': The Language of Loyalty in Qing Mongolia. Late Imperial China 21, 86-139.

Atwood, C. P. 2012. Banner, Otog, Thousand: Appanage Communities as the Basic Unit of Traditional Mongolian Society. Mongolian Studies: Journal of the Mongolia Society 34: 1-76.

Bawden, C. 1958. Two Mongol Texts Concerning Obo-Worship. Oriens Extremus 5: 23-41.

Bawden, C. 2015. Mongolian-English Dictionary. Abingdon: Routledge.

Booth, W. J. 1994. On the Idea of the Moral Economy. American Political Science Review 88: 653-67.

Botoeva, G. 2014. Hashish as Cash in a Post-Soviet Kyrgyz Village. International Journal of Drug Policy 25, 1227-34.

Browne, K. 2009. Economics and Morality: An Introduction. In K. Browne and B. L. Milgram, eds., Economics and Morality: Anthropological Approaches. Lanham: AltaMira Press, 1-40.

Carrier, J. G. 2018. Moral Economy: What's in a Name. Anthropological Theory 18: $18-35$.

Empson, R. 2011. Harnessing Fortune: Personhood, Memory and Place in Mongolia. Oxford: Oxford University Press.

Fernandez-Gimenez, M. E. 2010. Sustaining the Steppes: A Geographical History of Pastoral Land Use in Mongolia. Geographical Review 89: 315-42.

Götz, N. 2015. 'Moral Economy': Its Conceptual History and Analytical Prospects. Journal of Global Ethics 11: 147-62.

Guyer, J. I. 2004. Marginal Gains: Monetary Transactions in Atlantic Africa. Chicago: University of Chicago Press.

Hann, C. 2010. Moral Economy. In K. Hart, J-L. Laville, and A. D. Cattani, eds., The Human Economy. Cambridge: Polity, 187-98.

High, M. M. 2013. Polluted Money, Polluted Wealth: Emerging Regimes of Value in the Mongolian Gold Rush. American Ethnologist 40, 676-88.

High, M. M. 2017. Fear and Fortune: Spirit Worlds and Emerging Economies in the Mongolian Gold Rush. Ithaca: Cornell University Press.

High, M. M. and J. Schlesinger. 2010. Rulers and Rascals: The Politics of Gold in Mongolian Qing History. Central Asian Survey 29: 289-304.

Humphrey, C. 1995. Chiefly and Shamanist Landscapes in Mongolia. In M. O’Hanlon and E. Hirsch, eds., The Anthropology of Landscape: Perspectives on Place and Space. New York: Oxford University Press, 135-62. 
Humphrey, C., M. Mongush, and B. Telengid. 1993. Attitudes to Nature in Mongolia and Tuva: A Preliminary Report. Nomadic Peoples 33: 51-61.

Keane, W. 2019. How Everyday Ethics Becomes a Moral Economy, and Vice Versa. Economics Discussion Papers 2019-9. At: discussionpapers_2019-9.pdf (economics-ejournal.org) (last accessed 3 May 2021).

Li, T. M. 2015. Land's End: Capitalist Relations on an Indigenous Frontier. Oxford: International Institute of Social Studies.

Liddy, C. D. 2015. Urban Enclosure Riots: Risings of the Commons in English Towns, 1480-1525. Past \& Present 226, 1: 41-77.

Linebaugh, P. 2009. The Magna Carta Manifesto: Liberties and Commons for All. Berkeley: University of California Press.

Long, N. 2001. Development Sociology: Actor Perspectives. London: Routledge.

Luetchford, P. and G. Orlando. 2019. Introduction-Toward an Anthropology of the Just Price: History, Ethnography, and Critique. In P. Luetchford and G. Orlando, eds., The Politics and Ethics of the Just Price: Ethnographies of Market Exchange. Bingley: Emerald Publishing, 1-25.

Manning, Roger B. 1988. Village Revolts: Social Protest and Popular Disturbances in England, 1509-1640. New York: Clarendon Press.

Myadar, O. and S. Jackson. 2019. Contradictions of Populism and Resource Extraction: Examining the Intersection of Resource Nationalism and Accumulation by Dispossession in Mongolia. Annals of the American Association of Geographers 109: 36170 .

Natsagdorj, S. 1963. Manjiin Erhsheeld Baisan Üyeiin Halhyn Huraangüi Tü̈̈h. H. Perlee, ed. Ulaanbaatar: Ulsyn Hevleliin Hereg Erhleh Horoo.

Ochir, A. et al. 2003. Mongol Ulsyn Tü̈h: Dötgöör Bot' (XVII-XX Zuunii Ehen). A. Ochir and B. Enkh Güvchin, eds. Ulaanbaatar: Mongol Ulsyn Shinjleh Uhaany Akademi Tüühiin Hüreelen.

Ostrom, E. 1990. Governing the Commons: The Evolution of Institutions for Collective Action. Cambridge: Cambridge University Press.

Palomera, J. and T. Vetta. 2016. Moral Economy: Rethinking a Radical Concept. Anthropological Theory 16: 413-32.

Plueckhahn, R. 2020. Shaping Urban Futures in Mongolia: Ulaanbaatar, Dynamic Ownership and Economic Flux. London: University College of London Press.

Plueckhahn, R. and D. Bumochir. 2018. Capitalism in Mongolia: Ideology, Practice and Ambiguity. Central Asian Survey 37: 341-56.

Polanyi, K. 2001. The Great Transformation: The Political and Economic Origins of Our Time. $2 \mathrm{~d}$ ed. Boston: Beacon Press.

Rakopoulos, T. and K. Rio. 2018. Introduction to an Anthropology of Wealth. History and Anthropology 29: 275-91.

Rogers, J. D. 1987. The 1866 Grain Riots in Sri Lanka. Comparative Studies in Society and History 29: 495-513.

Roitman, J. 2003. Unsanctioned Wealth; or, the Productivity of Debt in Northern Cameroon. Public Culture 15: 211-37, 211.

Roitman, J. 2005. Fiscal Disobedience: An Anthropology of Economic Regulation in Central Africa. Princeton: Princeton University Press.

Rude, G. 2005. The Crowd in History: A Study of Popular Disturbances in France and England, 1730-1848. 3d ed. London: Serif Publishing. 
Salverda, T. 2020. Multiscalar Moral Economy: Global Agribusiness, Rural Zambian Residents, and the Distributed Crowd. Focaal-Journal of Global and Historical Anthropology (May): 1-14.

Scott, J. 1976. The Moral Economy of the Peasant: Rebellion and Subsistence in Southeast Asia. New Haven: Yale University Press.

Simoni, V. 2016. Economization, Moralization, and the Changing Moral Economies of 'Capitalism' and 'Communism' among Cuban Migrants in Spain. Anthropological Theory 16: 454-75.

Sneath, D. 2002. Mongolia in the 'Age of the Market': Pastoral Land-Use and the Development Discourse. In R. Mandel and C. Humphrey, eds., Markets and Moralities: Ethnographies of Postsocialism. New York: Routledge, 191-210.

Sneath, D. 2004. Property Regimes and Sociotechnical Systems: Rights over Land in Mongolia's 'Age of the Market.' In K. Verdery and C. Humphrey, eds., Property in Question: Value Transformation in the Global Economy. London: Bloomsbury Academic, 161-82.

Sneath, D. 2007. The Headless State: Aristocratic Orders, Kinship Society, and Misrepresentations of Nomadic Inner Asia. New York: Columbia University Press.

Sneath, D. 2010. Political Mobilization and the Construction of Collective Identity in Mongolia. Central Asian Survey 29: 251-67.

Sneath, D. 2018. Commonwealth, Inalienable Possessions, and the Res Publica: The Anthropology of Aristocratic Order and the Landed Estate. History and Anthropology 29: 324-41.

Sneath, D. and G. Munkherdene. 2018. Enclosing the Gold-Mining Commons of Mongolia. Current Anthropology 59: 814-38.

Swancutt, K. 2008. The Undead Genealogy: Omnipresence, Spirit Perspectives, and a Case of Mongolian Vampirism. Journal of the Royal Anthropological Institute 14: 843-64.

Thomas, Keith. 1969. Another Digger Broadside. Past \& Present 42, 1: 57-61.

Thompson, E. P. 1966. The Making of the English Working Class. New York: Vintage Books.

Thompson, E. P. 1971. The Moral Economy of the English Crowd in the Eighteenth Century. Past and Present 50: 76-136.

Thompson, E. P. 1991. Customs in Common: Studies in Traditional Popular Culture. London: Penguin Books.

Tilly, L. A. 1971. The Food Riot as a Form of Political Conflict in France. Journal of Interdisciplinary History 2: 23-57.

Tilly, L. A. 1983. Food Entitlement, Famine, and Conflict. Journal of Interdisciplinary History 14: 333-49.

Tsing, A. L. 2005. Friction: An Ethnography of Global Connection. Princeton: Princeton University Press.

Tsing, A. L. 2015. The Mushroom at the End of the World: On the Possibility of Life in Capitalist Ruins. Princeton: Princeton University Press.

Veit, V. and S. Rasidendog. 1975. Document 23: Petitions of Grievances Submitted by the People. Asiatische Forschungen 45: 209.

Velicu, I. and G. Garcia-Lopez. 2018. Thinking the Commons through Ostrom and Butler: Boundedness and Vulnerability. Theory, Culture and Society 35: 55-73. 
Walsh, A. J. and T. Lynch. 2008. The Morality of Money: An Exploration in Analytic Philosophy. New York: Palgrave Macmillan.

Watts, J. L. 2007. Public or Plebs: The Changing Meaning of "The Commons," 13811549. In H. Pryce and J. Watts, eds., Power and Identity in the Middle Ages: Essays in Memory of Rees Davies. Oxford: Oxford University Press, 242-60.

Whyte, D. and J. Wiegratz, eds. 2016. Neoliberalism and the Moral Economy of Fraud. Abingdon: Taylor \& Francis.

Wiegratz, J. 2016. Neoliberal Moral Economy: Capitalism, Socio-Cultural Change and Fraud in Uganda. London: Rowman \& Littlefield International.

Wingard, J. et al. 2018. Silent Steppe II: Mongolia's Wildlife Trade Crisis, Ten Years Later. London: Zoological Society of London.

Wong, R. Bin. 1982. Food Riots in the Qing Dynasty. Journal of Asian Studies 41: 767 88.

Zigon, J. 2007. Moral Breakdown and the Ethical Demand. Anthropological Theory 7: $131-50$.

\begin{abstract}
This article describes the development of the moral economy of merit among the fishermen and rural poor of Dalai Village, Magtaal soum, Mongolia. In 1971, the historian E. P. Thompson used the term "moral economy" to describe a popular consensus on what was considered right and wrong in economic behavior, arguing that its provocation motivated the eighteenth-century English poor to engage in crowd-based political action. In contemporary, post-socialist eastern Mongolia, the rural poor have constructed a pervasive local discourse on what is considered legitimate ("merit-making" or buyantai) versus what is illegitimate in economic behavior that morally-condones their illegal wildlife procurement, selling, and smuggling activities. The political contexts of these case studies are compared in order to detail a similar political-economic progression: (1) the recent market liberalization of the commons, sparking moral outrage amongst those classes newly disadvantaged through this shift to the market; and (2) the formation of an anti-profiteering moral discourse among these classes, designed to limit the ability of others to economically capitalize off of these circumstances. Comparing the case studies, the moral economy is manifested as exchange practices involving commons-marked goods that distribute their benefits among the participants, envisioned as thereby promoting group wellbeing rather than the uneven accumulation by individuals.
\end{abstract}

Key words: moral economy, E. P. Thompson, grain riots, Mongolia, wildlife trade, just price, merit, commons 